\title{
Increased reproducibility in RV mass measurement at end-systole
}

\author{
Stephan P Altmayer", Laurens A Teeuwen, Robert C Gorman, Yuchi Han \\ From 18th Annual SCMR Scientific Sessions \\ Nice, France. 4-7 February 2015
}

\section{Background}

Cardiovascular magnetic resonance (CMR) has been shown to be accurate and reproducible for right ventricular (RV) function evaluation. RV mass, assessed in enddiastolic (ED) phase, is one of the least reproducible CMR derived variables. The end-systolic (ES) phase could offer an alternative way to improve reproducibility, since the selection of basal slice and visualization of the usually thin RV wall are easier in this phase. Our goal was to evaluate the accuracy, reproducibility and contouring time for both ED and ES segmentation of the RV.

\section{Methods}

Clinical CMR exams were performed on a 1.5T Siemens scanner (Avanto, Siemens Health Systems, Germany) using a steady-state free precession (SSFP) sequence (flip angle $=55-75^{\circ}, \mathrm{TR}=25-35 \mathrm{~ms}, \mathrm{TE}=1.0-1.5 \mathrm{~ms}$, 30 cardiac phases, slice thickness of $8 \mathrm{~mm}$ ). Animal CMR were performed on a 3T Siemens scanner (Trio, Siemens Health Systems, Germany) using a SSFP sequence (flip angle $=45^{\circ}, \mathrm{TR}=25-30 \mathrm{~ms}$, TE $=1.5 \mathrm{~ms}$, 60 images per cardiac cycle, slice thickness of $4 \mathrm{~mm}$ ). Two observers - Observer 1 (Ob1), 6-months experienced, and Observer 2 (Ob2) with no previous experience - received practical training before the study began. RV mass and volumes were obtained in ES and ED phases using QMASS (Medis, Leiden, The Netherlands). To evaluate accuracy, 7 sheep hearts were imaged in vivo and then their RV free wall were weighted after removing epicardial fat. To assess reproducibility in clinical scans, Ob1 processed ventricular function of a 30 normal subjects. After at least 3 weeks, Ob1 and Ob2 reprocessed 15 randomly selected subjects. Absolute variability, Coefficient of variation $(\mathrm{CoV})$ and intraclass correlation coefficient (ICC) were used to evaluate intra

Cardiology, University of Pennsylvania, Philadelphia, PA, USA
Table 1 Weighted and CMR-derived RV mass (grams) in animal studies

\begin{tabular}{|c|c|c|c|c|c|}
\hline & \multirow{2}{*}{$\begin{array}{l}\text { Weighted } \\
\text { mass }\end{array}$} & \multicolumn{2}{|c|}{ End-diastolic phase } & \multicolumn{2}{|c|}{ End-systolic phase } \\
\hline & & $\begin{array}{c}\text { Observer } \\
1 \\
\end{array}$ & $\begin{array}{c}\text { Observer } \\
2 \\
\end{array}$ & $\begin{array}{c}\text { Observer } \\
1 \\
\end{array}$ & $\begin{array}{c}\text { Observer } \\
2 \\
\end{array}$ \\
\hline Sheep 1 & 34.4 & 30.75 & 28.7 & 32.45 & 30.3 \\
\hline Sheep 2 & 49.1 & 46.65 & 59.2 & 50.2 & 54.55 \\
\hline Sheep 3 & 38.85 & 35.55 & 39.65 & 40.5 & 36.95 \\
\hline Sheep 4 & 26.2 & 26.05 & 22.85 & 25.9 & 23.95 \\
\hline Sheep 5 & 57.6 & 50.6 & 49.1 & 52.75 & 50.45 \\
\hline Sheep 6 & 32.75 & 32.2 & 37.35 & 32.6 & 31.65 \\
\hline Sheep 7 & 32.4 & 28.85 & 29.2 & 30.45 & 30.25 \\
\hline $\begin{array}{c}\text { Mean } \\
\pm S D \\
\text { (p-value) }\end{array}$ & $38.7 \pm 10.9$ & \multicolumn{2}{|c|}{$\begin{array}{c}37.35 \pm 10.8 \\
(0.26)\end{array}$} & \multicolumn{2}{|c|}{$\begin{array}{c}36.9 \pm 10.8 \\
(0.24)\end{array}$} \\
\hline $\begin{array}{l}\text { Absolute } \\
\text { Variability }\end{array}$ & & \multicolumn{2}{|c|}{$5.6 \% \pm 3.5$} & \multicolumn{2}{|c|}{$8.7 \% \pm 3.9$} \\
\hline
\end{tabular}

and inter-observer variability. Segmentation time was recorded after the visual selection of ES and ED phases.

\section{Results}

Both phases were accurate to predict the weighted RV mass in animals (Table 1). ES presented less absolute variability $(5.6 \% \pm 3.6)$ than $\mathrm{ED}(8.7 \% \pm 3.9)$, despite not statistically significant $(\mathrm{p}=0.14)$. The intra- and interobserver reproducibility was higher in the ES phase for normal subjects. RV mass measured in the ED phase always yielded higher absolute variability and $\mathrm{CoV}$ than the ES phase (Table 2). Mean segmentation time (minutes $\pm \mathrm{SD})$ was significantly lower $(\mathrm{p}<0.001)$ in the ES than ED $(4.9 \pm 1.1$ vs. $6.6 \pm 1.2)$.

\section{Conclusions}

The assessment of RV mass is accurate, more reproducible and faster in ES phase. 
Table 2 Intra- and inter-observer variability of CMRderived RV mass in normal subjects

\begin{tabular}{lccccccc}
\hline & \multicolumn{3}{c}{ Intra-observer } & \multicolumn{3}{c}{ Inter-observer } \\
\cline { 2 - 8 } & $\begin{array}{c}\text { Absolute } \\
\text { Variability }\end{array}$ & CoV & ICC & $\begin{array}{c}\text { Absolute } \\
\text { Variability }\end{array}$ & CoV & ICC \\
\hline Diastole & $12.6 \% \pm 4.1$ & $9.1 \%$ & 0.88 & $18.6 \% \pm 9.7$ & $14.9 \%$ & 0.66 \\
\hline Systole & $6.6 \% \pm 5.1$ & $5 \%$ & 0.93 & $12.2 \% \pm 7.8$ & $7.9 \%$ & 0.84 \\
\hline
\end{tabular}

CoV, Coefficient of variation; ICC, Intraclass correlation coefficient.

\section{Funding}

Cardiovascular Medical Research and Education Fund.

Published: 3 February 2015

doi:10.1186/1532-429X-17-S1-Q40

Cite this article as: Altmayer et al.: Increased reproducibility in RV mass measurement at end-systole. Journal of Cardiovascular Magnetic Resonance 2015 17(Suppl 1):Q40

Submit your next manuscript to BioMed Central and take full advantage of:

- Convenient online submission

- Thorough peer review

- No space constraints or color figure charges

- Immediate publication on acceptance

- Inclusion in PubMed, CAS, Scopus and Google Scholar

- Research which is freely available for redistribution

Submit your manuscript at www.biomedcentral.com/submit 